Original Article

Open Access

\title{
Characterization of antibiotic resistance and species diversity of staphylococci isolated from apparently healthy farm animals
}

\author{
*Igbinosa, E. O., and Beshiru, A \\ Applied Microbial Processes \& Environmental Health Research Group, \\ Department of Microbiology, Faculty of Life Sciences, University of Benin, PMB 1154, Benin City, Nigeria \\ *Correspondence to: eigbinosa@gmail.com
}

\begin{abstract}
:
Background: Staphylococcus species are adaptable commensals usually involved in a diverse multiplicity of ailments in animals and humans. This study surveyed the occurrence, antibiotic-resistance profile and putative resistant genetic elements of staphylococci isolates from apparently healthy farm animals Methodology: Nasal and rectal samples were collected from a total of 400 cows and pigs in Benin City between May and December 2017. Staphylococci were isolated following aerobic cultures of samples using standard microbiological methods. Susceptibility profiles of the isolates to eighteen selected antimicrobials were determined using the Kirby-Bauer disk diffusion test. Species of staphylococci were established and antibiotic resistance genes detected by the polymerase chain reaction using species-specific and antibioticresistant primers respectively

Result: A total of 139 staphylococci isolates were phenotypically and genotypically identified from the foodproducing animals; $87(62.6 \%)$ from pigs and $52(37.4 \%)$ from cows. The most frequent Staphylococcus species were Staphylococcus haemolyticus 38 (27.3\%), Staphylococcus aureus 27 (19.4\%) and Staphylococcus capitis $21(15.1 \%)$. Antibiotic resistance profile showed $120(86.3 \%)$ isolates to be resistant to penicillin G, $100(71.9 \%)$ to nalidixic acid and $99(71.2 \%)$ to minocycline. The prevalence of antibiotic resistance genes assessed were mecA $78(56.1 \%)$, mphC $23(16.6 \%)$, and ermA $20(14.4 \%)$.

Conclusion: Our finding indicates that food animals are potential reservoirs of antibiotic resistant staphylococci which pose a significant threat to food security and public health.
\end{abstract}

Keywords: food animals; antibiotic-resistant; foodborne pathogen; staphylococci; resistance elements

Received March 21, 2019; Revised May 22, 2019; Accepted May 27, 2019

Copyright 2019 AJCEM Open Access. This article is licensed and distributed under the terms of the Creative Commons Attrition 4.0 International License (http://creativecommmons.org/licenses/by/4.0), which permits unrestricted use, distribution and reproduction in any medium, provided credit is given to the original author(s) and the source.

\section{Caractérisation de la résistance aux antibiotiques et de la diversité des espèces de staphylocoques isolés d'animaux de ferme apparemment en bonne santé}

\author{
*Igbinosa, E. O., et Beshiru, A
}

Groupe de recherche sur les processus microbiens appliqués et la santé environnementale, Département de microbiologie, Faculté des sciences de la vie, Université du Bénin, PMB 1154, Benin City, Nigéria.

*Correspondance à: eigbinosa@gmail.com

\begin{abstract}
Abstrait:
Contexte: Les espèces de Staphylococcus sont des agents commensaux adaptables généralement impliqués dans une grande diversité de maladies chez les animaux et les humains. Cette étude a examiné l'occurrence, le profil de résistance aux antibiotiques et les éléments génétiques potentiellement résistants d'isolats de staphylocoques provenant d'animaux d'élevage apparemment en bonne santé.

Méthodologie: Des échantillons nasaux et rectaux ont été prélevés chez 400 vaches et porcs au total dans la ville de Benin City entre mai et décembre 2017. Les staphylocoques ont été isolé suite à des cultures aérobies d'échantillons à l'aide de méthodes microbiologiques standard. Les profils de sensibilité des isolats à dix-huit antimicrobiens sélectionnés ont été déterminés à l'aide du test de diffusion sur disque Kirby-Bauer. Les espèces
\end{abstract}


de staphylocoques ont été établies et les gènes de résistance aux antibiotiques ont été détectés par réaction en chaîne de la polymérase en utilisant respectivement des amorces spécifiques à l'espèce et des bactéries résistantes aux

Résultat: Un total de 139 isolats de staphylocoques ont été identifiés phénotypiquement et génotypiquement à partir des animaux producteurs d'aliments. $87(62,6 \%)$ de porcs et $52(37,4 \%)$ de vaches. Les espèces de Staphylococcus les plus fréquentes étaient Staphylococcus haemolyticus 38 (27,3\%), Staphylococcus aureus $27(19,4 \%)$ et Staphylococcus capitis $21(15,1 \%)$. Le profil de résistance aux antibiotiques a montré que 120 $(86,3 \%)$ des isolats étaient résistants à la pénicilline G, $100(71,9 \%)$ à l'acide nalidixique et $99(71,2 \%)$ à la minocycline. La prévalence des gènes de résistance aux antibiotiques évalués était mecA $78(56,1 \%), m p h C 23$ $(16,6 \%)$ et ermA $20(14,4 \%)$.

Conclusion: nos résultats indiquent que les animaux destinés à l'alimentation sont des réservoirs potentiels de staphylocoques résistants aux antibiotiques qui constituent une menace importante pour la sécurité alimentaire et la santé publique

Mots-clés: animaux d'élevage; résistant aux antibiotiques; agent pathogène d'origine alimentaire; staphylocoques, éléments de résistance

\section{Introduction:}

Staphylococcus species are adaptable commensals usually involved in a diverse multiplicity of ailments in animals and humans with their pathogenicity associated with invasive capacity, antibiotic resistance, and toxin-mediated virulence $(1,2)$. In livestock, Staphylococcus aureus has been described as a significant cause of skin and soft tissue infections, mastitis and systemic infections (3) and is considered a key foodborne pathogen (4).

The demand for animal proteins is increasing globally at a relatively high rate for human consumption. Concern about the threat of antibiotic-resistant strains of Staphylococcus species has increased in recent years (5). The emergence of antibiotic resistance has been recognized to be the result of extensive prophylactic and therapeutic use of antimicrobials as growth promoters in food-producing animals $(6,7)$. Such antimicrobials are frequently used in human medicine for therapy of infections and prophylaxis during medical procedures such as surgeries, chemotherapy and organ transplantation (8). The widespread use of antimicrobials in food animals contribute to the development of antimicrobial-resistant bacteria (ARB) by means of natural selection and thus constitute a significant risk to public health.

Antibiotic resistance from animals can be disseminated to humans through food products (9), environment (10) and by direct contact to agricultural workers (11). Although it is difficult to establish a direct connection due to the organic character of antibiotic selection pressure, reports have shown a close relationship between the occurrence of livestock-associated antibioticresistant bacteria in humans and animals (12). Similarly, the rate of antimicrobial use in food-producing animals and the prevalence of antibiotic-resistant bacteria in humans (13) and animals (14) have been documented. Staphylococcus species from food-producing animals frequently harbour resistance elements. S. aureus are now generally resistant to methicillin and most other $\beta$-lactam antimicrobials. Methicillin resistance in staphylococci is mediated usually by mecA gene carried on staphylococcal chromosomal cassette (SCCmec) (15) which codes for altered penicillin-binding protein $2 a$ or $2^{\prime}$ (PBP2a or $2^{\prime}$ ) with low binding affinity to betalactamase resistant penicillins such as oxacillin and methicillin, and other betalactam antimicrobials (16).

The genotypic characterization of Staphylococcus species is essential to assess the risk of dissemination of resistant staphylococcal isolates between humans, environment and animals. There are enormous concern regarding the public health implication of methicillin-resistant $S$. aureus (MRSA) connected with livestock since MRSA and their resistance genes can spread from humans to animals via the food chain or through direct contact (17). Diversity of MRSA strains have been recovered from small ruminants or cow milk as well as different dairy products in different countries $(18,19)$.

In 2009, the European Food Safety Authority (EFSA) expressed growing concerns for public health orchestrated by the occurrence of MRSA in food animal production. The authority therefore suggested that additional studies be conducted on sampling, identification and characterization of MRSA carriage in animals and humans, and the environment coupled with food contamination (20). The current study aimed to characterize antibiotic resistant Staphylococcus species from food animals in Benin City, Nigeria.

\section{Materials and methods:}

\section{Sample collection}

A total of 400 samples (200 nasal and 200 rectal) samples were collected from cows and pigs in Benin City between May and 
December 2017. Samples were collected with sterile swabs by first moistening in sterile normal saline and gently swabbing the nasal and rectal cavities of the food-producing animals. Informed consent was obtained from the farm owners prior to sampling. Samples were immediately transported on ice packs to the Applied Microbial Processes and Environmental Health Research Group Laboratory, Department of Microbiology, University of Benin, Nigeria for analysis within 24 hours of collection.

\section{Culture isolation and biochemical identification of staphylococci \\ Swab samples were immediately} agitated on $5 \mathrm{~mL}$ tryptone soy broth (Lab M, Lancashire, United Kingdom) and incubated aerobically for $18-24$ hours at $37^{\circ} \mathrm{C}$. After 18 hours, an aliquot of $100 \mu \mathrm{L}$ was inoculated on mannitol salt agar (Lab M, Lancashire, United Kingdom) and further incubated aerobically for $18-24$ hours at $37^{\circ} \mathrm{C}$. After incubation, 'golden yellow' and other related colonies were Gram stained and identified by biochemical tests such as coagulase, DNAse, slide agglutination (BBL ${ }^{\mathrm{TM}}$ Staphyloslide ${ }^{\mathrm{TM}}$ ), and mannitol and sugar fermentation tests $(21,22)$. All tests were performed in triplicates with S. aureus ATCC 12600 used as control strain in each test procedure. The staphylococci isolates were confirmed with analytical profile index (API) Staph (BioMerieux, France). Identified staphylococci were colony purified on nutrient agar (Lab M, Lancashire, United Kingdom) and stored on nutrient agar slants at $4^{\circ} \mathrm{C}$ until further use.

\section{Susceptibility profile of staphylococci isolates} Susceptibility profile of the Staphylococcus species to antimicrobials was carried out using Kirby-Bauer/CLSI disk diffusion method (23). Briefly, the purified isolates were inoculated into $5.0 \mathrm{~mL}$ Mueller-Hinton broth (MHB) (Lab M, Lancashire, United Kingdom) and incubated overnight. The optical density (OD) of the turbidity of the broth was adjusted to OD of 0.5 McFarland standards which gives equivalence of $1 \times 10^{8}$ $\mathrm{CFU} / \mathrm{mL}$. Using a sterile swab, broth cultures were aseptically swabbed on Mueller Hinton agar (Lab M, Lancashire, United Kingdom). Antibiotic disks were aseptically placed on the agar plates with sterile forcep. Plates were incubated at $37^{\circ} \mathrm{C}$ for 24 hours and diameter of zone of inhibition for each isolate was measured with a ruler. Susceptibility or resistance of each isolate was determined by comparing the diameter of zone of inhibition with the interpretative chart of the Clinical and Laboratory Standards Institute (23). The antibiotic disks (Mast Diagnostics, Merseyside, United Kingdom) used were; meropenem $(10 \mu \mathrm{g})$, penicillin G (10 units), cefoxitin (30 $\mu \mathrm{g}$, surrogate for testing $S$. aureus against oxacillin), ceftazidime $(30 \mu \mathrm{g})$, cefotaxime $(30 \mu \mathrm{g})$, tetracycline $(30 \mu \mathrm{g})$, doxycycline $(30 \mu \mathrm{g})$, minocycline $(30 \mu \mathrm{g})$, clindamycin $(2 \mu \mathrm{g})$, erythromycin $(10 \mu g)$, ofloxacin $(5 \mu g)$, ciprofloxacin $(5 \mu \mathrm{g})$, levofloxacin $(5 \mu \mathrm{g})$, nalidixic acid $(30 \mu \mathrm{g})$, sulfamethoxazoletrimethoprim $(23.75 \mu \mathrm{g} / 1.25 \mu \mathrm{g})$, chloramphenicol $(30 \mu \mathrm{g})$, kanamycin $(30 \mu \mathrm{g})$, and gentamicin $(10 \mu \mathrm{g})$.

Multiple antibiotic resistance index of isolates The multiple antibiotic resistance index (MARI) for each isolate was calculated as number of antibiotics to which resistance occurred divided by the total number of antibiotics to which the isolate was tested (24). Multidrug resistance was defined as resistance to three or more antimicrobial classes (25).

\section{Genomic DNA extraction}

Genomic DNA from Staphylococcus isolates was extracted using the boiling method. Briefly, the Staphylococcus isolates were re-inoculated in $5.0 \mathrm{~mL}$ of tryptone soy broth and incubated at $37{ }^{\circ} \mathrm{C}$ for $18-24$ hours. Thereafter, $150 \mu \mathrm{L}$ of the cell suspension was dispensed into $2.0 \mathrm{~mL}$ Eppendorf tube, and the mixture was heated in a dry bath (MK200-2, Shanghai, China) for 15 minutes at $100{ }^{\circ} \mathrm{C}$ for cell lysis. The lysed cell mixture was centrifuged with the aid of a mini centrifuge (Mini 14 k, Zhuhai, Guangdong, China) at 14, 500 r/minute, for 5 minutes. The supernatant was carefully separated from the cell residues and stored at $-20^{\circ} \mathrm{C}$ as template target gDNA.

\section{PCR identification of Staphylococcus species} PCR was performed for all staphylococcal isolates using genus-specific and species-specific primers (Table 1 ). For genus specific amplification, the simplex PCR conditions used included denaturation at 96 ${ }^{\circ} \mathrm{C}$ for 3 minutes, followed by 40 cycles at 95 ${ }^{\circ} \mathrm{C}$ for $30 \mathrm{~s}$, annealing at $55^{\circ} \mathrm{C}$ for $60 \mathrm{~s}$, extension at $72{ }^{\circ} \mathrm{C}$ for $30 \mathrm{~s}$, with a final extension at $72{ }^{\circ} \mathrm{C}$ for 3 minutes (26) using a Peltier-based Thermal Cycler (MG96p/Y, Hangzhou, Zhejiang China). S. aureus ATCC 12600 served as positive control and nuclease-free water as negative control. The PCR products were electrophoresed on $1.5 \%$ agarose gel which was stained with ethidium bromide and visualized under the UV transilluminator (Vilber Lourmat, EBOX VX5, France).

Species-specific identification was carried out using multiplex PCR primers targeting S. epidermidis, S. saprophyticus, 
S. aureus and S. xylosus (at respective basepair size in Table 1 ) and the PCR conditions included denaturation at $94^{\circ} \mathrm{C}$ for 3 minutes followed by 40 cycles at $95{ }^{\circ} \mathrm{C}$ for $1 \mathrm{~s}$, annealing at $55^{\circ} \mathrm{C}$ for $30 \mathrm{~s}$, extension at 72 ${ }^{\circ} \mathrm{C}$ for $30 \mathrm{~s}$, with a final extension at $72{ }^{\circ} \mathrm{C}$ for 3 minutes (27). The PCR products were electrophoresed using $1.5 \%$ agarose gel (CLSAG100, Warwickshire, United Kingdom).

For other species, the multiplex PCR program conditions were denaturation at 94 ${ }^{\circ} \mathrm{C}$ for 10 minutes followed by 35 cycles at 94 ${ }^{\circ} \mathrm{C}$ for $15 \mathrm{~s}, 30 \mathrm{~s}$ at respective annealing temperature regimen for $S$. warneri $\left(60^{\circ} \mathrm{C}\right)$, S. haemolyticus $\left(50{ }^{\circ} \mathrm{C}\right.$ ) and $S$. capitis (59 ${ }^{\circ} \mathrm{C}$ ) respectively, and extension at $72{ }^{\circ} \mathrm{C}$ for $30 \mathrm{~s}(28)$.

\section{PCR detection of antibiotic resistance genes} PCR detection of macrolide-resistant genes (ermA, ermB, ermC, mphC) was done in accordance with multiplex PCR procedure of Sauer et al., (29) using primers presented in Table 2. PCR program conditions included an initial denaturation step for 5 minutes at $94^{\circ} \mathrm{C}$ followed by 30 cycles of denaturation for $60 \mathrm{~s}$ at $94{ }^{\circ} \mathrm{C}$, with the following respective annealing temperature regimen; ermA $\left(51^{\circ} \mathrm{C}\right)$, ermB $\left(51^{\circ} \mathrm{C}\right)$, ermC $\left(51^{\circ} \mathrm{C}\right)$, $m p h C\left(55^{\circ} \mathrm{C}\right)$ for $60 \mathrm{~s}$, and extension for 60 $\mathrm{s}$ at $72{ }^{\circ} \mathrm{C}$ with a final extension for 5 minutes at $72{ }^{\circ} \mathrm{C}(30,31,32)$.

PCR conditions for vanA and vanB genes included an initial denaturation for 5 minutes at $94^{\circ} \mathrm{C}$, followed by 10 cycles of denaturation for $30 \mathrm{~s}$ at $94^{\circ} \mathrm{C}$, annealing for $30 \mathrm{~s}$ at $64^{\circ} \mathrm{C}$, and extension for $45 \mathrm{~s}$ at 72 ${ }^{\circ} \mathrm{C}(33,34)$. PCR condition for mecA included an initial denaturation for 5 minutes at $94^{\circ} \mathrm{C}$, followed by 25 cycles, denaturation for $30 \mathrm{~s}$ at $94{ }^{\circ} \mathrm{C}$, annealing for $45 \mathrm{~s}$ at $50{ }^{\circ} \mathrm{C}$, and extension for 2 minutes at $72{ }^{\circ} \mathrm{C}$, with a final extension for 10 minutes at $72{ }^{\circ} \mathrm{C}(35)$.

Table 1: Primers used for staphylococci identification

\begin{tabular}{|c|c|c|c|c|}
\hline \multirow{3}{*}{$\begin{array}{c}\text { Microorganisms } \\
\text { Staphylococcus genus }\end{array}$} & Primers & Primer sequence $\left(5^{\prime}-3^{\prime}\right)$ & Size (bp) & References \\
\hline & TStaG422 & GGCCGTGTTGAACGTGGTCAAATCA & 370 & Martineau et al. (26) \\
\hline & TStag765 & TIACCATTTCAGTACCTTCTGGTA & & \\
\hline \multirow[t]{2}{*}{ S. haemolyticus } & ShaeF & GTTGAGGGAACAGAT & 85 & Iwase et al. (28) \\
\hline & ShaeR & CAGCTGTTTGAATATCTT & & \\
\hline S. capitis & ScapF & GCTAATTTAGATAGCGTACCTTCA & 208 & Iwase et al. (28) \\
\hline S. xylosus & $\begin{array}{l}\text { ScapR } \\
\text { XylF } \\
\text { XyIR }\end{array}$ & $\begin{array}{c}\text { CAGATCCAAAGCGTGCA } \\
\text { AACGCGCAACGTGATAAAATTAATG } \\
\text { AACGCGCAACAGCAATTACG }\end{array}$ & 539 & Morot-Bizot et al. (55) \\
\hline S. warneri & $\begin{array}{l}\text { SwarF } \\
\text { SwarR }\end{array}$ & $\begin{array}{l}\text { TGTAGCTAACTTAGATAGTGTTCCTTCT } \\
\text { CCGCCACCGTTATTTCTT }\end{array}$ & 63 & Iwase et al. (28) \\
\hline S. aureus & $\begin{array}{l}\text { Sa442-1 } \\
\text { Sa442-2 }\end{array}$ & $\begin{array}{l}\text { AATCTTTGTCGGTACACGATATTCTTCACG } \\
\text { CGTAATGAGATTTCAGTAGATAATACAACA }\end{array}$ & 1108 & Morot-Bizot et al. (55) \\
\hline S. saprophyticus & $\begin{array}{l}\text { Sap1 } \\
\text { Sap2 }\end{array}$ & $\begin{array}{l}\text { TCAAAAAGTITCTAAAAAATTTAC } \\
\text { ACGGGCGTCCACAAAATCAATAGGA }\end{array}$ & 221 & Morot-Bizot et al. (55) \\
\hline S. epidermidis & $\begin{array}{l}\text { Se705-1 } \\
\text { Se705-2 }\end{array}$ & $\begin{array}{l}\text { ATCAAAAAGTTGGCGAACCTITTCA } \\
\text { AAAAGAGCGTGGAGAAAAGTATCA }\end{array}$ & 1,124 & Morot-Bizot et al. (55) \\
\hline
\end{tabular}

Table 2: Primers used for amplification of antibiotic resistance genes in staphylococci isolates

\begin{tabular}{|c|c|c|c|c|}
\hline Genes & Primers & Primer sequence $\left(5^{\prime}-3^{\prime}\right)$ & Size (bp) & References \\
\hline mecA & $\begin{array}{l}\text { mecA1 } \\
\text { mecA2 }\end{array}$ & $\begin{array}{l}\text { GTAG AAAT GACT GAAC GTCC GATAA } \\
\text { CCAA TTCC ACAT TGTT TCGG TCTAA }\end{array}$ & 310 & Geha et al. (35) \\
\hline $\operatorname{van} \mathrm{A}$ & $\begin{array}{l}\operatorname{van} A 1 \\
\operatorname{van} A 2\end{array}$ & $\begin{array}{l}\text { GGGAAAACGACAATTGC } \\
\text { GTACAATGCGGCCGTTA }\end{array}$ & 732 & Dutka-Malen et al. (33) \\
\hline $\operatorname{van} B$ & $\begin{array}{l}\operatorname{van} B 1 \\
\operatorname{van} B 2\end{array}$ & $\begin{array}{l}\text { GTGC TGCG AGAT ACCA CAGA } \\
\text { CGAACACCATGCAACATTTC }\end{array}$ & 1145 & Ramos-Trujillo et al. (34) \\
\hline $\mathrm{mphC}$ & $\begin{array}{l}\mathrm{mph}(\mathrm{C})-1 \\
\mathrm{mph}(\mathrm{C})-2\end{array}$ & $\begin{array}{l}\text { GAGA CTAC CAAG AAGA CCTGACG } \\
\text { CATA CGCC GATT CTCC TGAT }\end{array}$ & 722 & Lüthje and Schwarz (30) \\
\hline ermA & $\begin{array}{l}\operatorname{erm}(A)-1 \\
\operatorname{erm}(A)-2\end{array}$ & $\begin{array}{l}\text { GCGGTAAACCCCTCTGAG } \\
\text { GCCTGTCGGAATTGG }\end{array}$ & 434 & Werckenthin and Schwarz (31) \\
\hline ermB & $\begin{array}{l}\operatorname{erm}(B)-1 \\
\operatorname{erm}(B)-2\end{array}$ & $\begin{array}{l}\text { CATT TAAC GACG AAAC TGGC } \\
\text { GGAA CATC TGTG GTAT GGCG }\end{array}$ & 425 & Jensen et al. (32) \\
\hline ermC & $\begin{array}{l}\operatorname{erm}(C)-1 \\
\operatorname{erm}(C)-2\end{array}$ & $\begin{array}{l}\text { ATCT TTGA AATC GGCT CAGG } \\
\text { CAAA CCCG TATT CCAC GATT }\end{array}$ & 295 & Jensen et al. (32) \\
\hline
\end{tabular}




\section{Results:}

Frequency of staphylococci isolation from mannitol salt agar

The frequency of Staphylococcus isolates recovered from the food producing animals in Table 3 shows an overall isolation rate from mannitol salt agar of $64.3 \%$ (257 of 400 ), with $98(24.5 \%)$ from cows (47 from nasal and 51 from rectal samples), and 159 $(39.8 \%)$ from pigs (83 from nasal and 76 from rectal samples).

Table 3: The frequency of isolation of Staphylococcus from culture of samples on mannitol salt agar

\begin{tabular}{|c|c|c|}
\hline & imber and source of samples examined & Number of samples positive for staphylococci \\
\hline \multirow[t]{2}{*}{ Cow } & nasal sample $(n=100)$ & $47(47)$ \\
\hline & rectal sample $(n=100)$ & $51(51)$ \\
\hline \multirow[t]{3}{*}{ Pig } & nasal sample $(n=100)$ & $83(83)$ \\
\hline & rectal sample ( $n=100)$ & $76(76)$ \\
\hline & Total $(n=400)$ & $247(64.3)$ \\
\hline
\end{tabular}

Distribution of the Staphylococcus species in cows and pigs

The frequency distribution of Staphylococcus species identified by both phenotypic and genotypic methods from cow and pigs is presented in Table 4. A total of 139 Staphylococcus species were identified from the 400 samples, giving a $34.8 \%$ recovery from these food animals, with 87 $(62.6 \%)$ from pigs (51 from nasal and 36 from rectal samples) and 52 (37.4\%) from cows (33 from nasal and 19 from rectal samples). The frequency distribution of the Staphylococcus species in descending order are; S. haemolyticus $(27.3 \%)$, S. aureus $(19.4 \%)$, S. capitis $(15.1 \%)$, S. epidermidis $(9.4 \%)$, S. saprophyticus $(7.2 \%)$, S. xylosus $(5.0 \%)$ and $S$. warneri (2.9\%). Other staphylococci species constituted $13.7 \%$.

Table 4: Frequency distribution of Staphylococcus species identified by phenotypic and genotypic methods from nasal and rectal samples of cow and pigs

\begin{tabular}{|c|c|c|c|c|c|c|c|}
\hline \multirow[b]{2}{*}{$\begin{array}{c}\text { Staphylococcus } \\
\text { species }\end{array}$} & \multicolumn{3}{|c|}{ Cow } & \multicolumn{3}{|c|}{ Pig } & \multirow[b]{2}{*}{ Total (\%) } \\
\hline & nasal & rectal & $\begin{array}{c}\text { Subtotal } \\
(\%)\end{array}$ & nasal & rectal & $\begin{array}{c}\text { Subtotal } \\
(\%)\end{array}$ & \\
\hline S. aureus & 11 & 3 & $14(26.9)$ & 8 & 5 & $13(14.9)$ & $27(19.4)$ \\
\hline S. epidermidis & 3 & 3 & $6(11.5)$ & 4 & 3 & $7(8.0)$ & $13(9.4)$ \\
\hline S. capitis & 5 & - & $5(9.6)$ & 13 & 3 & $16(18.4)$ & $21(15.1)$ \\
\hline S. xylosus & 3 & - & $3(5.8)$ & 3 & 1 & $4(4.6)$ & $7(5.0)$ \\
\hline S. haemolyticus & 5 & 5 & $10(19.2)$ & 10 & 18 & $28(32.2)$ & $38(27.3)$ \\
\hline S. saprophyticus & - & 3 & $3(5.8)$ & 7 & - & $7(8.0)$ & $10(7.2)$ \\
\hline S. warneri & 2 & 2 & $4(7.7)$ & - & - & - & $4(2.9)$ \\
\hline Other S. species & 4 & 3 & $7(13.5)$ & 6 & 6 & $12(13.8)$ & 19 (13.7) \\
\hline Total & 33 & 19 & $52(37.4)$ & 51 & 36 & $87(62.6)$ & 139 (100) \\
\hline
\end{tabular}

Table 5: Antimicrobial susceptibility profile of the Staphylococcus species

\begin{tabular}{ccccc}
\hline Antimicrobial class & Antibiotics & \multicolumn{3}{c}{ Staphylococcus species $(n=139)$} \\
\cline { 2 - 4 } & & Resistant & Intermediate & Sensitive \\
\hline Carbapenems & Meropenem & $18(12.9)$ & $0(0)$ & $121(87.1)$ \\
Penicillin & Penicillin G & $120(86.3)$ & $0(0)$ & $19(13.7)$ \\
Cephalosporins & Cefoxitin & $78(56.1)$ & $0(0)$ & $61(43.9)$ \\
& Ceftazidime & $72(51.8)$ & $43(30.9)$ & $24(17.3)$ \\
& Cefotaxime & $36(25.9)$ & $11(7.9)$ & $92(66.2)$ \\
Tetracyclines & Tetracycline & $102(73.4)$ & $0(0)$ & $37(26.6)$ \\
& Doxycycline & $91(65.5)$ & $12(8.6)$ & $36(25.9)$ \\
Lincosamides & Minocycline & $99(71.2)$ & $17(12.2)$ & $23(16.5)$ \\
Macrolides & Clindamycin & $46(33.1)$ & $24(17.3)$ & $69(49.6)$ \\
Quinolones & Erythromycin & $36(25.9)$ & $16(11.5)$ & $87(62.6)$ \\
& Ofloxacin & $14(10.1)$ & $18(12.9)$ & $107(76.9)$ \\
& Ciprofloxacin & $9(6.5)$ & $13(9.4)$ & $117(84.2)$ \\
Folate inhibitors & Levofloxacin & $12.2)$ & $0(0)$ & $136(97.8)$ \\
Phenicols & Nalidixic Acid & $100(71.9)$ & $0(0)$ & $0(0)$ \\
Aminoglycosides & Sulfamethoxazole-trimethoprim & $97(69.8)$ & $23(16.5)$ & $19(13.7)$ \\
& Chloramphenicol & $0(0)$ & $7(5.0)$ & $132(94.9)$ \\
& Kanamycin & $0(0)$ & $6(4.3)$ & $133(95.8)$ \\
\hline
\end{tabular}


Antimicrobial susceptibility profile of the staphylococci isolates

The resistant profile of the Staphylococcus species is presented in Table 5 which shows resistance rate to penicillin G of $86.3 \%$ ( 120 of 139 ), $71.9 \%$ to nalidixic acid, $71.2 \%$ to minocycline, $69.8 \%$ to trimethoprim-sulfamethoxazole, $65.5 \%$ to doxycycline, $56.1 \%$ to cefoxitin (oxacillin), $51.8 \%$ to ceftazidime, and $33.1 \%$ to clindamycin. The Staphylococcus species were sensitive to levofloxacin $97.8 \%$ (136 of $139), 95.8 \%$ to kanamycin, $94.9 \%$ to chloramphenicol, $92.1 \%$ to gentamycin, $87.1 \%$ to meropenem, $84.2 \%$ to ciprofloxacin, $76.9 \%$ to ofloxacin, $66.2 \%$ to cefotaxime and $62.6 \%$ to erythromycin.

Multidrug-resistance and multiple antibioticresistant index of Staphylococcus species The multidrug resistance profile of the Staphylococcus species as presented in Table 6 shows 100 (71.9\%) isolates resistant to three different antibiotic classes $\left(\mathrm{NAL}^{\mathrm{R}}, \mathrm{TET}^{\mathrm{R}}\right.$ and $\left.\mathrm{PEN}^{\mathrm{R}}\right), 67(48.2 \%)$ isolates

Table 6: Multidrug-resistant profile of the Staphylococcus species

\begin{tabular}{|c|c|c|c|c|}
\hline $\begin{array}{c}\text { Number of } \\
\text { antimicrobial class }\end{array}$ & $\begin{array}{l}\text { Number of } \\
\text { antibiotics }\end{array}$ & Resistance phenotype & $\begin{array}{l}\text { Number of } \\
\text { isolates } \\
(n=139)\end{array}$ & MARI \\
\hline 3 & 3 & $\mathrm{NAL}^{\mathrm{R}}, \mathrm{TET}^{\mathrm{R}}, \mathrm{PEN}^{\mathrm{R}}$ & $100(71.9)$ & 0.17 \\
\hline 4 & 5 & $T M P^{R}, N A L^{R}, M^{\prime} N^{R}, T E T^{R}, P E N^{R}$ & $96(69)$ & 0.27 \\
\hline 4 & 6 & $T_{M P P^{R}}, N A L^{R}, M^{\prime} N^{R}, D O X^{R}, T^{\prime} T^{R}, P E N^{R}$ & $90(64.7)$ & 0.33 \\
\hline 5 & 7 & $T_{M P}^{R}, N^{\prime} L^{R}, M^{R} N^{R}, D O X^{R}, T^{\prime} T^{R}, C^{\prime} Z^{R}, P E N^{R}$ & $70(50.4)$ & 0.35 \\
\hline 5 & 8 & TMP $^{R}$, NAL $^{R}$, MIN $^{R}, D^{\prime} X^{R}, T^{\prime} T^{R}, C^{\prime} Z^{R}, O X A^{R}, P E N^{R}$ & $67(48.2)$ & 0.39 \\
\hline 6 & 9 & 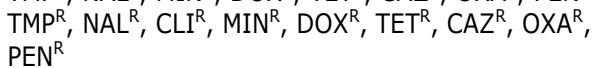 & $45(32.4)$ & 0.50 \\
\hline 7 & 11 & $\begin{array}{l}\text { TMP }^{R}, \text { NAL }^{R}, \mathrm{ERY}^{\mathrm{R}}, \mathrm{CLI}^{\mathrm{R}}, \mathrm{MIN}^{\mathrm{R}}, \mathrm{DOX}^{\mathrm{R}}, \mathrm{TET}^{\mathrm{R}}, \mathrm{CTX}^{\mathrm{R}}, \\
\mathrm{CAZ}^{\mathrm{R}}, \mathrm{OXA}^{\mathrm{R}}, \mathrm{PEN}^{\mathrm{R}}\end{array}$ & $35(25.2)$ & 0.61 \\
\hline 8 & 12 & $\begin{array}{l}\text { TMP }^{R}, N^{\prime} L^{R}, E^{R} Y^{R}, C^{R} I^{R}, M^{R} N^{R}, D^{R} X^{R}, T^{R} T^{R}, C^{R} X^{R}, \\
C^{R} Z^{R}, O^{R}, P^{R} N^{R}, M^{R}\end{array}$ & $16(11.5)$ & 0.67 \\
\hline 8 & 13 & $\begin{array}{l}T_{M P^{R}}, N^{\prime} L^{R}, O F X^{R}, E^{R} Y^{R}, C^{R} I^{R}, M^{R} N^{R}, D^{\prime} O X^{R}, T^{R} T^{R}, \\
C T X^{R}, C^{R}, O^{R}, P^{R}, N^{R}, M^{R} M^{R}\end{array}$ & $13(9.4)$ & 0.72 \\
\hline 8 & 14 & $\begin{array}{l}T_{M P^{R}}{ }^{\prime} \mathrm{NAL}^{\mathrm{R}}, \mathrm{CIP}^{\mathrm{R}}, \mathrm{ERY}^{\mathrm{R}}, \mathrm{CLI}^{\mathrm{R}}, \mathrm{MIN}^{\mathrm{R}}, \mathrm{DOX}^{\mathrm{R}}, \mathrm{TET}^{\mathrm{R}}, \\
\mathrm{CTX}^{\mathrm{R}}, \mathrm{CAZ}^{\mathrm{R}}, \mathrm{OXA}^{\mathrm{R}}, \mathrm{PEN}^{\mathrm{R}}, \mathrm{MEM}^{\mathrm{R}}\end{array}$ & $9(6.5)$ & 0.78 \\
\hline 8 & 15 & 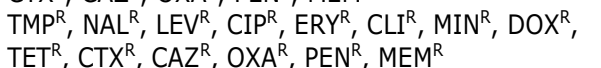 & $3(2.2)$ & 0.83 \\
\hline
\end{tabular}

MEM: Meropenem, PEN: Penicillin G, OXA: Oxacillin, CAZ: Ceftazidime, CTX: Cefotaxime, TET: Tetracycline, DOX: Doxycycline, MIN: Minocycline, CLI: Clindamycin, ERY: Erythromycin, OFX: Ofloxacin, CIP: Ciprofloxacin, LEV: Levofloxacin, NAL: Nalidixic Acid, TMP: Trimethoprimsulfamethoxazole, CHL: Chloramphenicol, KAN: Kanamycin, GEN: Gentamycin, Values in parenthesis denote percentage. MARI: multiple antibiotic resistance index

Table 7: Distribution of antibiotic-resistant genes

\begin{tabular}{ccc}
\hline Antibiotic-resistant genes & $\begin{array}{c}\text { No of phenotypically resistant isolates to } \\
\text { the antibiotics used }\end{array}$ & $\begin{array}{c}\text { Frequency of resistance genes screened } \\
(\%)\end{array}$ \\
\hline mecA & 78 & $78(100)$ \\
vanA & ND & 12 \\
vanB & $N D$ & 0 \\
$m p h C$ & 36 & $23(63.8)$ \\
ermA & 36 & $20(55.6)$ \\
ermB & 36 & $4(11.1)$ \\
ermC & 36 & $11(30.6)$ \\
\hline
\end{tabular}

$\mathrm{ND}=$ Not Determined 


\section{Discussion:}

This study characterized staphylococci isolates from two food animals, cow and pigs, which are common source of animal proteins consumed in our environment. The most frequently identified staphylococci in descending order from the food animals in our study are S. haemolyticus (27.3\%, $\mathrm{n}=38)$, S. aureus $(19.4 \%, \mathrm{n}=27))$, S. capitis $(15.1 \%, \mathrm{n}=21), \mathrm{S}$. epidermidis $(9.4 \%$, $\mathrm{n}=13), S$. saprophyticus $(7.2 \%, \mathrm{n}=10), S$. xylosus $(5.0 \%, \mathrm{n}=7$ ) and $S$. warneri $(2.9 \%$, $\mathrm{n}=4$ ). This is different from the pattern in a similar study by Chajecka-Wierzchowska et al., (36), where the most frequently identified staphylococci were $S$. xylosus $(n=29,50 \%)$, S. epidermidis $(n=16,27.6 \%)$, S. lentus $(n=7,12.1 \%), S$. saprophyticus $(n=4,6.9 \%), S$. hyicus $(n=11.7 \%)$ and $S$. simulans ( $n=1$ 1.7\%). Although S. xylosus, $S$. epidermidis and $S$. saprophyticus were identified in both studies, S. haemolyticus, S. aureus and $S$. capitis, the three most frequently isolated staphylococci in our study were absent in Chajecka-Wierzchowska et al., study while $S$. hyicus, $S$. simulans and $S$. lentus isolated in their study were completely absent in our study.

In the study by Taponen et al., (37) on bovine mastitic milk, the most common coagulase negative staphylococci species identified were S. simulans, S. epidermidis, $S$. chromogenes and $S$. haemolyticus which are similar to the ones from our study on food animals with respect to $S$. epidermidis and $S$. haemolyticus. Also, in the study by Beyene et al., (38) on 193 samples collected from abattoir and dairy farms, 92 (47.7\%) were positive for Staphylococcus species with S. aureus $(n=31 ; 16.1 \%), S$. intermedius $(n=21 ; 10.9 \%)$, S. hyicus $(n=16 ; 8.3 \%)$, and other coagulase negative staphylococci $(n=24 ; 12.4 \%)$. The differences in the species of staphylococci identified in different studies may be related to geographical distribution and methods employed in identification of the species from the animals.

There have been reports of alarming high levels of $S$. aureus resistance to commonly used antimicrobials such as tetracycline and penicillins (including amoxicillin) in cows $(39,40)$. The high resistance of staphylococci isolates in our study to penicillin $(86 \%)$, tetracycline $(73 \%)$, sulfamethoxazole-trimethoprim (72\%), cefoxitin (surrogate for oxacillin, 56\%), and ceftazidime (52\%) agrees with reports from earlier studies $(39,40)$, which suggest that antimicrobial resistance must have developed in the staphylococci isolates occasioned by indiscriminate and prolonged use of antimicrobials. Chajecka-Wierzchowska et al., (36) reported that most of the staphylococci isolates from ready-to-eat food of animal origin in their study were resistant to cefoxitin $(41.3 \%)$, clindamycin $(36.2 \%)$, tigecycline $(24.1 \%)$, rifampicin $(17.2 \%)$ and erythromycin $(13.8 \%)$. Majority of the staphylococci isolates from Beyene et al., (38) study also demonstrated resistance to cefoxitin (55.8\%), vancomycin $(65.1 \%)$, cloxacillin (79.1\%), nalidixic acid (88.4\%) and penicillin G (95.3\%). These largely agree with some of the findings in our study.

The staphylococci isolates in Beyene et al., (38) study were multidrug resistant, exhibiting resistance to more than three antibiotic classes, which agrees with findings of the present study, with about $72 \%$ of the staphylococci isolates showing resistance to three or more classes of antibiotics. The multidrug resistance rate in our study is however higher that the $32.2 \%$ reported by Chajecka-Wierzchowska et al., (36). The predominant multidrug resistance phenotype reported from 46 isolates reported by $\mathrm{Li}$ et al., (41) was penicillin-ampicillin-kanamycingentamicin-tetracycline but this differs from the commonest phenotype, penicillintetracycline-nalidixic acid, reported in the current study.

Globally, livestock farming has improved food production at a reduced cost per unit produced with several pitfalls from increased antimicrobial resistance. This present study has further strengthened the fact that food animals can act as reservoir for antimicrobial resistant Staphylococcus species. Linking antimicrobial ingestion in food animals to drug-resistant infections of humans is intrinsically complex due to the environmental nature of the selection pressure for antibiotic-resistant pathogens as well as the occurrence of non-specific routes of transmission throughout the environment. An increasing body of evidence has emerged to strengthen the fact that repeated usage of antimicrobials in intensive livestock farming systems lead to antimicrobial resistance, which is of clinical importance in human medicine $(42,43)$.

The resistance of $S$. aureus and other staphylococci isolates to beta-lactams such as penicillin $\mathrm{G}$ and oxacillin is very evident. Resistance to Penicillin $G$ is a significant concern since this antibiotic is the major antibiotic group that is recommended for staphylococcal mastitic infection. The frequent therapeutic usage of antibiotics in cows may lead to selection and dissemination of resistant strains even as Jaims et al., (44) reported that the development of antimicrobial resistance occurs from repeated therapeutic and/or indiscriminate use of antimicrobials. Resistance to antibiotics is 
usually expressed on mobile genetic elements such as plasmids and transposons that can be disseminated from one staphylococcal species to another (45). S. aureus resistance to penicillin $\mathrm{G}$ is due to the production of beta lactamase enzyme carried on transmissible plasmids, which inactivates penicillin and other beta-lactam antimicrobials. This study also demonstrated the occurrence of macrolide resistance both phenotypically and genotypically. Resistance to macrolide and lincosamide has previously been reported in coagulase negative staphylococci (CoNS) including S. epidermidis recovered from cows with mastitis (46). In this study, all phenotypically methicillin resistant staphylococci (cefoxitin resistance) carried the mecA gene while $64 \%, 56 \%, 11 \%$ and $31 \%$ of the isolates that were phenotypically resistant to erythromycin respectively carried the macrolide resistance genes; $m p h C$, ermA, ermB and ermC. This is similar to the findings of Chajecka-Wierzchowska et al., (36) where all the MRSA strains in their study also harboured mecA gene but the erythromycin resistant isolates carried only the ermC gene. However, $84 \%$ of mecApositive strains reported by Vyletelova et al., (47) expressed resistance to cefoxitin in the disk diffusion test. In the study by Couto et al., (48) conducted on animals over a 16 year period, the mecA gene was identified in $11.6 \%$ of the staphylococcal isolates which included MRSA $(40.7 \%)$, methicillin resistant Staphylococcus pseudintermedius (8.7\%) and methicillin-resistant coagulase negative staphylococci $(26.7 \%)$. The prevalence of mecA gene in their study was low compared to our study and this difference could be related to differences in the food animals studied. Saputra et al., (49) also reported an overall low frequency of mecA gene among S. pseudintermedius and S. aureus as $11.8 \%$ and $12.8 \%$ respectively from animals but Ruzauskas et al., (50) reported 20 of 21 mecA gene in methicillin resistant staphylococci obtained from 395 clinical samples of diseased animals while the remaining one (1) isolate was positive for mecC gene.

The mecA gene encodes abnormal penicillin-binding protein $2 a$ or $2^{\prime}$ (PBP2a or PBB2') which has a low binding affinity for $\beta$ lactam antibiotics. Therefore, this group of antibiotics is not effective against bacteria expressing mecA gene. Expression of mecA gene however depends on a number of factors such as media type, $\mathrm{pH}$, incubation temperature and presence of beta-lactam agents in the medium (51). The gene may therefore remain silent and unexpressed if these optimum conditions are not met. Other possibility includes mutations in the promoter or coding region of the gene. In addition, staphylococcal isolate may carry another mec gene types such as mecB, mecC or mecD, which may also express abnormal PBPs that can cause methicillin resistance (50).

Vancomycin has often be regarded as the last line of antibiotic for staphylococci infections as most isolates have been reported to be sensitive to the antibiotic (52). However, findings from our study revealed that some staphylococci carried vanA, the gene that has been reported to be responsible for high level resistance to vancomycin in S. aureus (53). We could not test our isolates against vancomycin with the CLSI recommended broth dilution or E-test method (23) because this was not available in our centre at the time of this study. This resistant strain (vancomycin resistant $S$. aureus, VRSA) could constitute another important challenge to public health in the near future.

\section{Conclusion:}

Antibiotic resistance in pathogens is usually associated with mobile genetic elements such as plasmids, conjugative transposons and integrons (54). Selection and proliferation of antibiotic-resistant strains can occur, and these can be spread to the environment through animal wastes leading to increase in the resistance reservoir pool in the environmental microbiome (55). Findings from our study revealed a high prevalence of antibiotic-resistant Staphylococcus species in food-producing animals in Benin City, Nigeria, which could have resulted from overuse of antibiotics which acts as selection pressure and from poor hygiene practices of the animal handlers which is responsible for spread of the resistant pathogens. Improving hygienic measures in handling of foodproducing animals and stopping the routine use of antibiotics as prophylactic, therapeutic or growth promoters in animal feeds or water are crucial public health measures.

\section{Conflicts of Interest:}

Authors declare no conflict of interest

\section{Acknowledgements:}

Authors are grateful to 2013/2014 Tertiary Education Trust fund (TETFUND) Nigeria, Research Project Intervention [Year 2015 TETFUND Research Project Fund $8^{\text {th }}$ Batch] for financial support 


\section{References:}

1. Argudin, M. A., Mendoza, M. C., and Rodicio, M. R. Food poisoning and Staphylococcus aureus enterotoxins. Toxins. 2010; 2: 1751-1773

2. Abebe, M., Daniel, A., Yimtubezinash, W., and Genene, T. Identification and antimicrobial susceptibility of Staphylococcus aureus isolated from milk samples of dairy cows and nasal swabs of farm workers in selected dairy farms around Addis Ababa, Ethiopia. Afr J Microbiol Res. 2013; 7: 3501-3510

3. Carfora, V., Caprioli, A., Marri, N., Sagrafoli, D., Boselli, C., Giacinti, G., Giangolini, G., Sorbara, L., Dottarelli, S., Battisti, A., and Amatiste, S. Enterotoxin genes, enterotoxin production, and methicillin resistance in Staphylococcus aureus isolated from milk and dairy products in Central Italy. Int Dairy J. 2015; 42: 12-15

4. Hennekinne, J. A., Ostyn, A., Guillier, F., Herbin, S., Prufer, A. L., and Dragacci, S. How should staphylococcal food poisoning outbreaks be characterized? Toxins. 2010; 2: 2106-2116

5. Igbinosa, E. O., Beshiru, A., Akporehe, L. U., and Ogofure, A. G. Detection of methicillinresistant staphylococci isolated from foodproducing animals: A public health implication. Vet Sci. 2016; 3: 14-26.

6. Normanno, G., Corrente, M., La Salandra, G., Dambrosio, A., Quaglia, C., Parisi, A., Greco, G., Bellacicco, A., Virgilio, S., and Celano, G. Methicillin-resistant Staphylococcus aureus (MRSA) in foods of animal origin product in Italy. Int J Food Microbiol. 2007; 117: 219-222

7. Tassew, A., Negash, M., Demeke, A., Feleke, A., Tesfaye, B., and Sisay, T. Isolation, identification and drug resistance patterns of methicillin-resistant Staphylococcus aureus from mastitic cow's milk from selected dairy farms in and around Kombolcha, Ethiopia. J Vet Med Animal HIth. 2016; 8: 1-10.

8. Laxminarayan, R., Duse, A., Wattal, C., Zaidi, A. K. M., Wertheim, H. F. L., and Sumpradit, N. Antibiotic resistance-the need for global solutions. Lancet Infect Dis. 2013; 13: 10571098

9. Price, L. B., Johnson, E., Vailes, R., and Silbergeld, E. Fluoroquinolone resistant Campylobacter isolates from conventional and antibiotic-free chicken products. Environ HIth Perspect. 2005; 113: 557-560

10. Graham, J. P., Evans, S. L., Price, L. B., and Silbergeld, E. K. Fate of antimicrobial-resistant enterococci and staphylococci and resistance determinants in stored poultry litter. Environ Res. 2009; 109: 682-689

11. Smith, T. C., Gebreyes, W. A., Abley, M. J., Harper, A. L., Forshey, B. M., Male, M. J., Martin, H. M., Srinand-Sreevatsan, B. Z., Thakur, S., Thiruvengadam, M., and Davies, P. R. Methicillin-resistant Staphylococcus aureus in pigs and farm workers on conventional and antibiotic-free swine farms in the USA. PLoS One. 2013; 8: e63704

12. Vieira, A. R., Collignon, P., Aarestrup, F. M., McEwen, S. A., Hendriksen, R. S., Hald, T., and Wegener, H. C. Association between antimicrobial resistance in Escherichia coli isolates from food animals and bloodstream isolates from humans in Europe: An ecological study. Foodborne Pathog Dis. 2011; 8: 12951301

13. Schwarz, S., Kehrenberg, C., and Walsh, T. R. Use of antimicrobial agents in veterinary medicine and food animal production. Int J Antimicrob Agents. 2001; 17: 431-437

14. Aarestrup, F. M. Veterinary drug usage and antimicrobial resistance in bacteria of animal origin. Basic Clin Pharmacol Toxicol. 2005; 96: 271-281

15. Kwon, N., Park, K., Jung, W., Youn, H., Lee, Y.,
Kim, S., Bae, W., Lim, J., Kim, J. Y., Kim, J. M., Hong, S., and Park, Y. Characteristics of methicillin-resistant Staphylococcus aureus isolated from chicken meat and hospitalized dogs in Korea and their epidemiological relatedness. Vet Microbiol. 2006; 117: 304-312

16. Igbinosa, E. O., Beshiru, A., Akporehe, L. U., Oviasogie, F. E., and Igbinosa, O. O. Prevalence of methicillin-resistant Staphylococcus aureus and other Staphylococcus species in raw meat samples intended for human consumption in Benin City, Nigeria: Implications for public health. Int J Environ Res Publ HIth. 2016; 13: 949-961

17. Kluytmans, J. Methicillin resistant Staphylococcus aureus in food products: cause for concern or case for complacency? Clin Microbiol Infect. 2010; 16: 11-15

18. Ünal, N., Askar, Ş., Macun, H., Sakarya, F., Altun, B., and Yıldırım, M. Panton-Valentine leukocidin and some exotoxins of Staphylococcus aureus and antimicrobial susceptibility profiles of staphylococci isolated from milks of small ruminants. Trop Animal HIth Prod. 2012; 44: 573-579

19. Beshiru, A., Igbinosa, I., and Igbinosa, E. Antimicrobial resistance of methicillin-resistant staphylococci isolated from food-producing animal. 17th International Congress on Infectious Diseases. Int J Infect Dis. 2016; 45: S $1-4$

20. European Food Safety Authority (EFSA). Assessment of the public health significance of methicillin-resistant Staphylococcus aureus (MRSA) in animals and foods - scientific opinion of the panel on biological hazards. Eur Food Safety Authority J. 2009; 993: 1-73

21. Cruickshank, R., Duguid, J. P., Marmion, B. R. and Swain, R. H. Medical Microbiology, 12th edition, Churchill Livingstone; Edinburgh, UK, 1975

22. Cheesbrough, M. Microbiological Test. In District Laboratory Practice in Tropical Countries; Part 2; Cambridge University Press: New York, NY, USA, 2000: 442

23. Clinical and Laboratory Standards Institute (CLSI), Performance Standards for Antimicrobial Susceptibility Testing M02-A12, M07-A10, and M11-A8. 27th edition; 2017; 282

24. Krumperman, P. H. Multiple antibiotic resistance indexing of Escherichia coli to identify high-risk sources of faecal contamination of foods. Appl Environ Microbiol. 1983; 46: 165-170

25. Magiorakos, A. P., Srinivasan, A., Carey, R. B. Carmeli, $Y$., Falagas, M. E., Giske, C. G., Harbarth, S., Hindler, J. F., Kahlmeter, G., and Olsson-Liljequist, B. Multidrug resistant, extensively drug resistant and pan-drugresistant bacteria: An international expert proposal for interim standard definitions for acquired resistance. Clin Microbiol Infect. 2012; 18: 268-281

26. Martineau, F., Picard, F. J., Ke, D., Paradis, S., and Roy, P. H. Development of a PCR assay for identification of staphylococci at genus and species levels, J Clin Microbiol. 2001; 39: 25412547

27. Corbière, M. S., Talon, R., and Leroy, S. Development of a multiplex PCR for the identification of Staphylococcus genus and four staphylococcal species isolated from food. J Appl Microbiol. 2004; 97: 1087-1094

28. Iwase, T., Seki, K., Shinji, H., Mizunoe, Y., and Masuda, S. Development of a real-time PCR assay for the detection and identification of Staphylococcus capitis, Staphylococcus haemolyticus, and Staphylococcus warneri. J Med Microbiol. 2007; 56: 1346-1349

29. Sauer, P., Sila, J., Stosova, T., Vecerova, R., and Hejnar, P. Prevalence of genes encoding extracellular factors among methicillin-resistant Staphylococcus aureus isolates from the 
University Hospital, Olomouc, Czech Republic. ] Med Microbiol. 2008; 57: 403-410

30. Lüthje, P., and Schwarz, S. Antimicrobial resistance of coagulase-negative Staphylococci from bovine subclinical mastitis with particular reference to macrolide-lincosamide resistance phenotypes and genotypes. J Antimicrob Chemother. 2006; 57: 966-969

31. Werckenthin, C., and Schwarz, S. Molecular analysis of the translational attenuator of a constitutively expressed ermA gene from Staphylococcus intermedius. J Antimicrob Chemother. 2000; 46: 785-788

32. Jensen, L. B., Frimodt-Moller, N., and Aarestrup, F. M. Presence of erm gene classes in Grampositive bacteria of animal and human origin in Denmark. FEMS Microbiol Lett. 1999; 170: 151158

33. Dutka-Malen, S., Evers, S., and Courvalin, P. Detection of glycopeptide resistance genotypes and identification to the species level of clinically relevant enterococci by PCR. J Clin Microbiol. 1995; 33: 24-27

34. Ramos-Trujillo, E., Perez-Roth, E., MendezAlvarez, S., and Claverie-Martin, F. Multiplex PCR for simultaneous detection of enterococcal genes vanA and vanB and staphylococcal genes mecA, ileS-2, and femB. Int Microbiol. 2003; 6: 113-115

35. Geha, D. J., Uhl, J. R., Gustaferro, C. A., and Persing, D. H. Multiplex PCR for identification of methicillin-resistant staphylococci in the clinical laboratory. J Clin Microbiol. 1994; 32: 17681772

36. Chajecka-Wierzchowska, W., Zadernowska, A., Nalepa, B., Sierpinska, M., and ŁaniewskaTrokenheima, L. Coagulase negative staphylococci (CoNS) isolated from ready-to-eat food of animal origin: phenotypic and genotypic antibiotic resistance. Food Microbiol. 2015; 46: 222-226

37. Taponen, S., Nykäsenoja, S., Pohjanvirta, T., Pitkälä, A., and Pyörälä, S. Species distribution and invitro antimicrobial susceptibility of coagulase-negative staphylococci isolated from bovine mastitic milk. Acta Vet Scand. 2016; 58: 12

38. Beyene, T., Hayishe, H., Gizaw, F., Beyi, A.F., Abunna, F., Mammo, B., Ayana, D., Waktole, H., and Abdi, R. D. Prevalence and antimicrobial resistance profile of Staphylococcus in dairy farms, abattoir and humans in Addis Ababa, Ethiopia. BMC Res. Notes. 2017; 10: 171

39. Edward, M., Anna, K., Michal, K., Henryka, L., and Krystyna, K. Antimicrobial susceptibility of staphylococci isolated from mastitic cows. Bull Vet Inst Pulawy. 2002; 289-294

40. Gentilini, E., Denamiel, G., Betancor, A., Rebuelto, M., Fermepin, M., and De Torres, R. Antimicrobial susceptibility of coagulasenegative staphylococci isolated from bovine mastitis in Argentina. J Dairy Sci. 2002; 85 (8): 1913-1917.

41. Li, L., Zhou, L., Wang, L., Xue, H., and Zhao, X. Characterization of methicillin-resistant andsusceptible staphylococcal isolates from bovine milk in Northwestern China. PLoS One. 2015; 10 (3): e0116699

42. Sarmah, A. K., Meyer, M. T., and Boxall, A. B. A. A global perspective on the use, sales, exposure pathways, occurrence, fate and effects of veterinary antibiotics (VAs) in the environment. Chemosphere. 2006; 65 (5): 725759

43. Laxminarayan, R. Extending the Cure: Policy Responses to the Growing Threat of Antibiotic Resistance. Resource Future, Washington, DC, 2007

44. Jaims, E., Montros, L., and Renata, C. Epidemiology of drug resistance; the case of Staphylococcus aureus and coagulase negative staphylococci infections. Salud Publica Mex. 2002; 44 (2): 108-112.

45. Hulya, T., Senay, E., and Dilek, O. Antibiotic resistance of Staphylococcus aureus and coagulase-negative staphylococci isolated from bovine mastitis. Bull Vet Inst Pulawy. 2006; 50 (1): 41-45.

46. Sawant, A. A., Gillespie, B. E., and Oliver, S. P. Antimicrobial susceptibility of coagulasenegative Staphylococcus species isolated from bovine milk. Vet Microbiol. 2009; 134: 273-281

47. Vyletelova, M., Vlkova, H., and Manga, I. Occurrence and characteristics of methicillin resistant Staphylococcus aureus and methicillin resistant coagulase negative staphylococci in raw milk manufacturing. Czech J Food Sci. 2011; 29: S11-S16

48. Couto, N., Monchique, C., Belas, A., Marques, C., Gama, L.T., and Pomba, C. Trends and molecular mechanisms of antimicrobial resistance in clinical staphylococci isolated from companion animals over a 16 year period. J Antimicrob Chemother. 2016; 71: 1479-1487

49. Saputra, S., Jordan, D., Worthing, K. A., Norris, J. M., Wong, H. S., and Abraham, R. Antimicrobial resistance in coagulase-positive staphylococci isolated from companion animals in Australia: A one year study. PLoS One. 2017; 12: e0176379.

50. Ruzauskas, M., Couto, N., Kerziene, S., Siugzdiniene, R., Klimiene, I., Virgailis, $M$, and Pomba, C. Prevalence, species distribution and antimicrobial resistance patterns of methicillinresistant staphylococci in Lithuanian pet animals. Acta Veterinar Scandinavica. 2015; 57: 27

51. Chambers, H. F. Methicillin resistant staphylococci. Clin Microbiol Rev. 1988; 1(2): 173-186

52. Pehlivanoglu, F., and Yardimci, H. Detection of methicillin and vancomycin resistance in Staphylococcus strains isolated from Bovine milk samples with mastitis. Kafkas Univ Vet Fak Derg. 2012; 18: 849-855

53. Périchon $B$, and Courvalin $P$. VanA-type vancomycin-resistant Staphylococcus aureus. Antimicrob. Agents Chemother. 2009; 53: 4580-4587

54. Economou, V., and Gousia, P. Agriculture and food animals as a source of antimicrobialresistant bacteria. Infect Drug Res. 2015; 8: 49-61

55. Morot-Bizot, S. C., Talon, R., and Leroy, S. Development of a multiplex PCR for the identification of Staphylococcus genus and four staphylococcal species isolated from food. J Appl Microbiol. 2004; 97: 1087-1094 